\title{
Effect of Plant Material and Variety for Production and Quality Chrysanthemum
}

\author{
I Gusti Made Arjana, Yohanes Parlindungan Situmeang, I Nengah Suaria, Ni Komang Sulasmini Mudra \\ \# Faculty of Agriculture, Warmadewa University, Denpasar, Bali, Indonesia \\ E-mail:igm.arjana@gmail.com,ypsitumeang63@gmail.com
}

\begin{abstract}
The purpose of this study was to determine the effect between types of cuttings and between varieties of plant material on any type of plant material chrysanthemum cuttings. Methods trial with a randomized block design factorial nested pattern. The results showed that the treatment effect of plant cuttings type of material does not give a significant effect on all parameters observed. Influence of cuttings between varieties at any plant material gives a significant influence on the parameters, the maximum number of leaves, flower stalks weight and economical weight of fresh flowers. The average weight of the highest economical due to the influence between the varieties in each type of plant material cuttings from mother plants found in fiji white varieties $93.83 \mathrm{~g}$ and not significant with $93.46 \mathrm{~g}$ fiji yellow varieties. So also in effect between varieties on any type of cuttings from the plant material production plant gives the same result.
\end{abstract}

Keywords - Materials plant cuttings; varieties; production; quality chrysanthemum.

\section{INTRODUCTION}

Chrysanthemum (Dendranthema grandiflora, Tzvelev Syn.) Is one of the flagship floriculture products are developed to meet the domestic market [1]. The applicability of chrysanthemums on each wreath is dominant up to 30$65 \%$. It is prospective to grow in both quality, quantity and industrial development effort chrysanthemum. This is an exciting opportunity for people who want to develop business chrysanthemum [4]. The cultivation of chrysanthemum was originally concentrated in Java, has now spread to Bali. Chrysanthemum is a commodity that has economic value that is high enough so that the potential to be developed commercially as a basic component in agribusiness well as cut flowers, potted plants, and medicinal plants [5].

Chrysanthemum flower production, especially Bali have not been able to meet the needs of the market because of productivity is still low and still growing areas cultivated by certain farmers. Potential areas that have not been all planted with ornamental plants, due to various considerations such as the remoteness of the marketing center, there is no adequate infrastructure, limited knowledge of cultivating, harvesting, and postharvest handling [3]. Increased production through intensification frequently encountered problems include the provision of planting material (cuttings) quality, especially farmers who are outside Java, spacing, arrangement soil moisture by mulching, determination of optimum dose of organic and inorganic fertilizers, postharvest (sorting, grading and packaging) and the management of production systems. Factors that aquaculture is a cause of low production and quality of chrysanthemum flowers that influence the selling price as a cut flower chrysanthemum. Based on the above, then do research on the effects of plant material and varieties for the production and quality of chrysanthemum flowers.

\section{MATERIALS AND METHODS}

The study was conducted in the village of Pancasari, District Sukasada, Buleleng, Bali, with a height of 1,247 meters above sea level and an average temperature of $17^{\circ} \mathrm{C}$ to $20{ }^{\circ} \mathrm{C}$. This study begins in January 2015 and ended in December 2015.

The method in this research is to use nested experiment with randomized block design, where the variety of factors nested in each type of cutting material. Cuttings treatment plant material consists of two types, namely the production plant cuttings (Sp) and the parent plant cuttings ( $\mathrm{Si}$ ). Treatment consists of varieties with 3 types (Figure 1), namely jaguar red varieties $(\mathrm{Vj})$, fiji white varieties $(\mathrm{Vw})$, and varieties of yellow fiji $(\mathrm{Vy})$.

Each treatment was repeated 4 times, so that the required 24-plot trial, the distance between plots treated $30 \mathrm{~cm}$ while the distance between replications of $50 \mathrm{~cm}$, wide swath 
experiment $1 \mathrm{mx} 1 \mathrm{~m}$ with a population of 64 plants. The parameters observed among others: plant height, number of leaves, stem diameter, stem length flower, flower stalk weight, flower diameter, and weighs economical fresh flowers.

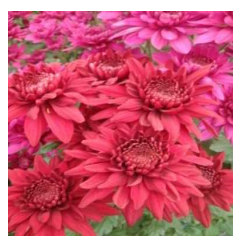

Jaguar Red

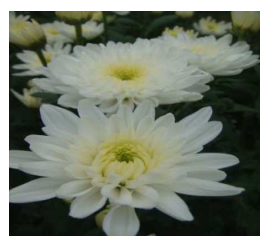

White Fiji

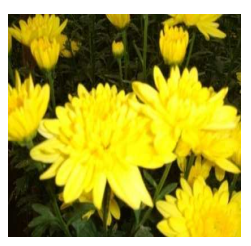

Yellow Fiji
Fig. 1 Type chrysanthemum varieties under study

\section{RESULTS AND DISCUSSION}

Significance influence cuttings kinds of plant material (S) and varieties (V) on all parameters were observed in chrysanthemum can be seen in Table 1. Average effect between types of cuttings and between varieties of plant material on any type of cuttings of the plant material on chrysanthemum against the average maximum plant height, maximum leaf number, stem diameter, heavy flower stalks, flower diameter, and weighs economical fresh flowers are presented in Tables 2 and 3.

TABLE I

Significance EFFect Cuttings Plant Material (S) AND VARIETy (V) of All PARAMETERS OBSERVABLE

\begin{tabular}{|ll|c|c|}
\hline \multirow{2}{*}{\multicolumn{1}{|c|}{ Parameter }} & \multicolumn{2}{|c|}{ Treatment } \\
\cline { 2 - 3 } & $\begin{array}{c}\text { Cuttings Plant } \\
\text { Materials }\end{array}$ & $\begin{array}{c}\text { Plant } \\
\text { Varieties }\end{array}$ \\
\hline 1. & Plant height $(\mathrm{cm})$ & $\mathrm{ns}$ & $\mathrm{ns}$ \\
2. & Leaves number (strand) & $\mathrm{ns}$ & $* *$ \\
3. & Stem diameter $(\mathrm{cm})$ & $\mathrm{ns}$ & $\mathrm{ns}$ \\
4. & Flower stalk length $(\mathrm{cm})$ & $\mathrm{ns}$ & $\mathrm{ns}$ \\
5. & Flower stalk Weight $(\mathrm{g})$ & $\mathrm{ns}$ & $* *$ \\
6. & Flower diameter $(\mathrm{cm})$ & $\mathrm{ns}$ & $\mathrm{ns}$ \\
7. & Economic weight of fresh & $\mathrm{ns}$ & $* *$ \\
& flowers $(\mathrm{g})$ & & \\
\hline
\end{tabular}

Results of statistical analysis showed that the effect between types of cuttings of plant material (S) effect was not significant $(\mathrm{P}>0.05)$ on all parameters observed, it is likely due to the positive influence of these two factors mutually affect each of the results of the experiment and naturally have almost the same genetic potential to support plant growth and development. While the influence between varieties (V) on any type of cuttings of the plant material (S) gives a significant influence $(\mathrm{P}<0.01)$ in to the parameter number of maximum leaf, heavy flower stalks, and the weighting economical fresh flowers as well as the effect is not significant to the parameters of other (Table 1).

Yellow varieties influence between Fiji (V) on any type of cuttings of the plant material $(\mathrm{S})$ production produces the highest average value of the maximum number of leaves (37.56 strands), the weight of the flower stalk (137.80 g) and the economical weight of fresh flowers ( $93.83 \mathrm{~g})$ and significantly different varieties of red jaguar (Tables 2 and 3).
The same also between varieties obtained on the effect of any type of cuttings from the parent plant except the maximum plant height significantly.

TABLE II

Effect Cuttings Plant And Variety of Plant High Average MAXIMUM AMOUNT MAXIMUM LEAF, STEM DIAMETER AND LONG FLOWER STALK

\begin{tabular}{|c|c|c|c|c|}
\hline Treatment & $\begin{array}{l}\text { Plant } \\
\text { height } \\
(\mathrm{cm})\end{array}$ & $\begin{array}{l}\text { Leaves } \\
\text { number } \\
\text { (strand) }\end{array}$ & $\begin{array}{c}\text { Stem } \\
\text { diameter } \\
(\mathrm{cm})\end{array}$ & $\begin{array}{l}\text { Flower stalk } \\
\text { length }(\mathrm{cm})\end{array}$ \\
\hline \multicolumn{5}{|c|}{ Effect of Plant Material Type Cuttings (S) } \\
\hline $\mathrm{Sp}$ & $128.87 \mathrm{a}$ & $34.11 \mathrm{a}$ & $0.695 \mathrm{a}$ & $151.37 \mathrm{a}$ \\
\hline $\mathrm{Si}$ & $126.44 \mathrm{a}$ & $35.73 \mathrm{a}$ & $0.764 \mathrm{a}$ & $148.94 \mathrm{a}$ \\
\hline BNT 5\% & ns & ns & ns & ns \\
\hline \multicolumn{5}{|c|}{ Effect of Variety (V) on each type Cuttings (S) } \\
\hline $\mathrm{SpVj}$ & $119.75 \mathrm{a}$ & $27.69 \mathrm{~b}$ & $0.66 \mathrm{a}$ & $144.75 \mathrm{a}$ \\
\hline SpVw & $133.81 \mathrm{a}$ & $37.56 \mathrm{a}$ & $0.73 \mathrm{a}$ & $153.81 \mathrm{a}$ \\
\hline SpVy & $133.03 \mathrm{a}$ & $37.06 \mathrm{a}$ & $0.69 \mathrm{a}$ & $155.53 \mathrm{a}$ \\
\hline $\mathrm{SiVj}$ & $110.88 \mathrm{~b}$ & $30.85 \mathrm{~b}$ & $0.73 \mathrm{a}$ & $142.13 \mathrm{a}$ \\
\hline $\mathrm{SiVw}_{\mathrm{w}}$ & $132.13 \mathrm{a}$ & $38.03 \mathrm{a}$ & $0.77 \mathrm{a}$ & $154.63 \mathrm{a}$ \\
\hline SiVy & $136.31 \mathrm{a}$ & $38.31 \mathrm{a}$ & $0.79 \mathrm{a}$ & $150.06 \mathrm{a}$ \\
\hline BNT 5\% & 20.26 & 4.84 & ns & ns \\
\hline
\end{tabular}

Description: The average value followed by the same letter on the facto and the same column showed no real difference in the level of 5\% LSD.

TABLE IIII

EFFECT OF CUtTINGs Plant AND VARIETy of Average Weight Flower STALKS, DiAMETER OF INTEREST, AND ECONOMIC WEIGHT OF FRESH FLOWERS

\begin{tabular}{|c|c|c|c|}
\hline Treatment & $\begin{array}{c}\text { Flower stalk } \\
\text { Weight } \\
(\mathrm{g})\end{array}$ & $\begin{array}{c}\text { Flower } \\
\text { diameter } \\
(\mathrm{cm}) \\
\end{array}$ & $\begin{array}{c}\text { Economic } \\
\text { weight of fresh } \\
\text { flowers }(\mathrm{g})\end{array}$ \\
\hline \multicolumn{4}{|c|}{ Effect of Plant Material Type Cuttings (S) } \\
\hline $\mathrm{Sp}$ & $118.72 \mathrm{a}$ & $9.14 \mathrm{a}$ & $87.08 \mathrm{a}$ \\
\hline $\mathrm{Si}$ & $108.49 \mathrm{a}$ & $8.89 \mathrm{a}$ & $86.28 \mathrm{a}$ \\
\hline BNT 5\% & ns & ns & ns \\
\hline \multicolumn{4}{|c|}{ Effect of Variety (V) on each type Cuttings (S) } \\
\hline $\mathrm{SpVj}$ & $90.58 \mathrm{~b}$ & $7.83 \mathrm{a}$ & $73.96 \mathrm{~b}$ \\
\hline SpVw & $137.58 \mathrm{a}$ & $9.75 \mathrm{a}$ & $93.83 \mathrm{a}$ \\
\hline SpVy & $128.00 \mathrm{a}$ & $9.63 \mathrm{a}$ & $93.46 \mathrm{a}$ \\
\hline $\mathrm{SiVj}$ & $79.78 \mathrm{~b}$ & $8.53 \mathrm{a}$ & $69.65 \mathrm{~b}$ \\
\hline SiVw & $121.42 \mathrm{a}$ & $9.22 \mathrm{a}$ & $97.50 \mathrm{a}$ \\
\hline SiVy & $124.29 \mathrm{a}$ & $8.94 \mathrm{a}$ & $91.71 \mathrm{a}$ \\
\hline BNT 5\% & 25.72 & $\mathrm{~ns}$ & 13.32 \\
\hline
\end{tabular}

Description: The average value followed by the same letter on the factor and the same column showed no real difference in the level of 5\% LSD.

Influence between varieties $(\mathrm{V})$ on any type of material of plant cuttings (S), both of which are used from the parent plant and crop production gives the same effect on the economic weight of fresh flowers. While the average weight of economical fresh flowers on the use of cuttings from mother plants higher when compared with cuttings of plants from plant production, this suggests that the production plants still have capabilities similar to the parent plant to be used as cuttings for growth and development plant. It should also be supported by proper breeding techniques to produce seed production is fast and quality. Chrysanthemum many vegetatively bred artificially by using partially stems, roots, or leaves of the plants to be grown into new plants [2]. Artificial vegetative propagation is easy to do and quick in getting the desired new offspring. Various types of artificial vegetative propagation include vegetative propagation by 
cuttings. The success of a good cutting quality greatly depends on the method of determining the plant healthy and old enough, choose healthy shoots growing shoots at the base of 3-5 $\mathrm{mm}$ diameter, $5 \mathrm{~cm}$ long, and has three adult leaves bright green.

\section{CONCLUSIONS}

The influence of the type of material of plant cuttings no significant effect on all parameters were observed. Between varieties influence on any type of material cuttings of the plant production is very real effect on the maximum number of leaves, flower stalks weight and economical weight of fresh flowers. Fiji yellow varieties of fresh flowers produce the highest economic weight $(93.83 \mathrm{~g})$ when compared with other varieties.

Between varieties influence on any type of material cuttings from mother plants provide a very real effect on plant height maximum, the maximum number of leaves, flower stalks weight and economical weight of fresh flowers. Fiji yellow varieties of fresh flowers produce the highest economic weight $(97.50 \mathrm{~g})$ when compared with other varieties.
Cuttings from the parent plant or production plant for yellow or white varieties fiji can be used by the farmer to obtain the production and quality of chrysanthemum plants better, especially in facing the problem of the availability of seeds chrysanthemum.

\section{ACKNOWLEDGMENT}

Much obliged for DP2M DIKTI which have funded Decentralization Research Competitive Grant in 2015. Thanks also goes to all those who have helped this research.

\section{REFERENCES}

[1] Balai Penelitian Tanaman Hias, 2006. Teknologi Produksi Krisan Pusat Penelitian dan Pengembangan Hortikultura Badan Penelitian dan Pengembangan Pertanian

[2] Budiarto, K. dan B. Marwoto, 2007. Produktivitas Tanaman Induk dan Kualitas Stek Varietas Krisan di Rumah Plastik dan Lahan Terbuka. Jurnal Hortikultura 17 (4) : 321-327

[3] Darti, 1992."Tanaman dan Budidaya Tanaman Hias", Penerbit Mahkota, Jakarta.

[4] Direktorat Budidaya dan Pascapanen Florikultura, 2013. Profil Krisan. Dirjen Hortikultura, Kementrian Pertanian.

[5] Rukmana, HR. 1997. Krisan. Penerbit Kanisius. Yogyakarta. 